\title{
Tari Golek Gambyong Gaya Yogyakarta
}

\author{
Tutik Winarti ${ }^{1}$ \\ Jurusan Tari, Fakultas Seni Pertunjukan, Institut Seni Indonesia
}

\begin{abstract}
Gambyog Dance of Yogyakarta. Tari Golek Gambyong merupakan satu-satunya tari golek gaya Yogyakarta yang berbentuk tari kelompok. Tari ini merupakan koreografi lama yang dicipta KGPA Mangkubumi pada masa pemerintahan Sri Sultan Hamengku Buwana VI. Tari Golek Gambyong dibawakan oleh tiga orang penari, dengan peran dan karakter yang berbeda, yaitu satu peran putri sebagai Golek, dua peran putra masing-masing menjadi Kakang Gambyong dan Canthang Balung. Diperkirakan tari ini merupakan penggambaran adanya intrik politik yang terjadi pada masa itu atau sebagai sindiran bagi yang berseteru pada masa itu. Saat tari itu diciptakan, dalam keraton sedang terjadi intrik politik yang terkenal dengan nama pergolakan Suryengalaga.
\end{abstract}

Key words: tari, sindiran, Suryengalaga.

\section{Pendahuluan}

Tari Golek merupakan salah satu tari klasik gaya Yogyakarta yang sangat populer. Ada banyak koreografi Tari Golek yang berkembang saat ini. Tari ini merupakan representasi seorang remaja putri yang sedang berada dalam masa liminalitas dan untuk menemukan jati dirinya dia berusaha membangun kepercayaan diri dengan cara berhias. (Winarti, 1997:5-10)

Melalui beberapa koleksi manuskrip tari yang dikoleksi KRT Pujaningrat (RM Dinusatomo), terdapat satu buku kumpulan catatan Tari Golek yang ditulis oleh KRT Wiroguno putra KGPA Mangkubumi. Manuskrip yang ditulis dengan huruf Jawa ini berisi 13 koreografi Tari Golek lama. Salah satu dari ke 13 bentuk Tari Golek lama tersebut terdapat satu bentuk yang sangat berbeda dengan yang lain, yaitu Tari Golek Gambyong.

Tari Golek Gambyong merupakan satu-satunya Tari Golek yang berbentuk tari kelompok, sedangkan bentuk Tari Golek yang lain merupakan tari tunggal. Tari Golek Gambyong dicipta oleh KGPA Mangkubumi, hal ini terlihat dari cakepan gerongan yang berbunyi:

Kawuwusa Golek Gambyong kang pinurwa, pusaka pinarsudi, Yasan Gusti Pangeran Mangkubumi minulya, Hing Ngajogjakarta nagri, Putra narendra kang kaping nem mandhiri.
(Tersebutlah Golek Gambyong yang akan ditampilkan, pusaka yang dipelihara, karya Yang Mulia Gusti Pangeran Mangkubumi, Di negeri Yogyakarta, Putra raja yang keenam).

Tari Golek Gambyong dibawakan oleh tiga orang penari, yang masing-masing mempunyai peran sendiri-sendiri. Peran-peran itu adalah, satu peran putri sebagai Golek, dua peran putra masing-masing menjadi Kakang Gambyong dan Canthang Balung.

Dilihat dari namanya "Golek Gambyong", tari ini berkesan sebagai penggabungan dua tarian dari dua daerah menjadi satu, yaitu Tari Golek dari Yogyakarta dan Tari Gambyong dari Surakarta. Kebetulan kedua tari itu mempunyai beberapa kesamaan, misalnya kesejajaran jenis dan karakter. Kesamaan juga terdapat pada proses pembentukannya, kedua tari itu pada awalnya sama-sama sangat lekat dengan tledhek. Melalui proses yang panjang kedua tari itu sama-sama merupakan bentuk tari hasil dari akulturasi budaya rakyat dan budaya istana. Kedua tari itu merupakan tari tunggal putri dan sama-sama berfungsi sebagai tari tontonan. Pada perkembangan selanjutnya di Surakarta lahir dan berkembang juga Tari Golek. Beberapa ahli tari mengatakan lahirnya Tari Golek di Surakarta mendapat pengaruh yang besar dari keberadaan Tari Golek gaya Yogyakarta. Golek Gambyong bukan merupakan penggabungan Tari Golek dan Tari Gambyong. Tari Golek Gambyong

1 Alamat korespondensi: Prodi Tari, FSP ISI Yogyakarta, jalan Parangtritis KM. 6,5. Sewon, Yogyakarta 55001. Hp: 081328803933; e-mail: tutikwin@yahoo.com 
murni merupakan tari gaya Yogyakarta dan tidak terdapat pengaruh dari Tari Gambyong.

Banyak keunikan terdapat dalam Tari Golek Gambyong, di antaranya terdapat tiga peran di dalamnya, yaitu: Canthang Balung, Golek dan Gambyong. Jika ditelaah dari masing-masing nama peran yang ada, juga mempunyai kesamaan nama dengan nama tari lain atau tokoh budaya lain. Adanya Canthang_Balung (yang sebenarnya bukan milik budaya Yogyakarta), di samping itu, peran putrinya yang disebut Golek menjadi unik, karena sebenarnya Golek sendiri merupakan tari tunggal putri. Demikian pula peran Gambyong yang identik dengan nama tari tunggal putri gaya Surakarta. Dalam Tari Golek Gambyong, Golek menjadi bagian dari sebuah tari. Fenomena ini sangat menarik dan dapat menimbulkan teba tafsir yang luas.

\section{Koreografi Golek Gambyong}

Melihat gerak tari yang dilakukan penari Golek serta busana yang dikenakannya, boleh dikata tidak ada perbedaannya bila dibandingkan dengan Tari Golek yang lain. Perbedaannya terletak pada konsep pelaku, peran Golek dalam tari ini menggambarkan seseorang yang sudah bersuami. Konsep seperti itu tersirat dalam teks yang ditembangkan oleh penarinya, yang antara lain tertulis :

Golek berkata

\section{: Kakang gambyong lamun sira, Tanmituhu bujar ami, Luwih becik pepisahan, Tanpa gawe sun ladeni, Kerep ngundur sayekti, Wit wus sulayeng panemu.}

(Kakang Gambyong jika kamu, tidak mendengarkan kata saya, lebih baik berpisah, tidak ada gunaya saya mengabdi, sering bertengkar (perang mulut) karena adanya perbedaan pendapat.

Gambyong menjawab :

Mas mirah semut abang, Roning Jendraling wong ngarbi, Haku gemang yen

pisah lawan sira.

(Mas mirah semut abang,

Roning Jendraling

(ungkapan) orang

berumah tangga, saya

tidak mau berpisah dengan

kamu).

Jika peran Golek dalam tari ini sebagai wanita yang sudah bersuami, berarti ia sudah dewasa, tidak lagi dalam masa liminalitas. Bagi wanita di Jawa yang telah berumah tangga dianggap sebagai wanita dewasa, artinya sudah menemukan jati dirinya. Hal ini memunculkan pertanyaan, mengapa tetap saja memakai nama golek. Budaya Jawa adalah budaya simbol dan makna, segala sesuatunya terkonsep dengan kandungan simbol yang penuh dengan makna. Oleh karena itu, sepertinya tidak mungkin jika penamaan peran putri itu dengan nama Golek jika tidak mempunyai atau mengandung makna tertentu.

Makna kata golek dalam bahasa Jawa berarti mencari, jadi tetap saja makna dari peran itu adalah pencarian tentang "sesuatu". Berdasarkan pengamatan dan pengkajian yang telah dilakukan, peran Golek dalam Tari Golek Gambyong, mempunyai makna agar penonton mencari inti dari tari itu sendiri. Melalui fenomena yang dapat ditangkap, tari itu gambaran adanya permasalahan yang terjadi pada lingkungan budaya itu tumbuh.

Ungkapan isi dialognya yang berwujud tembang, menunjukkan bahwa tari ini menyiratkan adanya suatu konflik, namun jika dilihat dari geraknya, konflik yang ada tidak nampak sama sekali. Secara keseluruhan struktur gerak peran Golek boleh dikatakan sama dengan Tari Golek lain, yang dapat dibagi menjadi tiga bagian, yaitu: bagian awal atau maju beksan, bagian tengah atau inti beksan dan bagian akhir atau mundur beksan.

Maju Beksan atau bagian awal dimulai dari gerak sembahan yang dilakukan di sebelah kiri tempat pentas atau sebelah kanan penonton. Setelah berdiri, melakukan gerakan untuk menuju ke tengah. Gerak yang dipergunakan adalah kapang-kapang dan kicat. Setelah di area tengah, penari kembali duduk. Tahap ini berakhir ketika bunyi gendhing berhenti (suwuk). Gendhing yang dipergunakan dalam maju beksan, adalah gendhing Durma Bugis Slendro Manyura. Maju 
Beksan adalah bagian awal dari tari, merupakan penghantar untuk menuju ke esensi tari. Bagian ini tidak mempunyai makna yang berkaitan dengan konsep tema, namun hanya merupakan kebutuhan koreografi semata. Bagian ini selalu ada pada hampir semua bentuk tari, walaupun panjang pendeknya sangat relatif sekali.

Bagian tengah atau Inti Beksan, merupakan bagian yang paling penting dalam sebuah tarian. Pada bagian inilah esensi tari dapat terlihat. Pada Tari Golek Gambyong, bagian ini dimulai ketika dimulainya gendhing Kinanthi Jangga, sedangkan gerakan yang mengawali bagian ini juga sembahan. Sebelum sampai pada gerak yang paling pokok dan merupakan ciri khas dalam Tari Golek yaitu muryani busana, tahapan ini diawali dengan gerakan nggrudha. Nggrudha adalah gerak yang mirip gerak ngenceng. Gerak ngenceng, merupakan gerak baku dalam tari putri gaya Yogyakarta. Berkaitan dengan gerak baku, hampir semua koreografi konvensional untuk tari putri dapat dipastikan mempergunakan gerak ngenceng atau nggrudha. Dalam Tari Golek Gambyong, gerak nggrudha diulang sampai $18 \mathrm{kali}$, yang terdiri dari nggrudha kanan dan nggrudha kiri. Gerak muryani busana yang dipergunakan dalam Tari Golek Gambyong, adalah: keplok asta, tasikan, atrap jamang, ngunggar sinom, atrap slepe, atrap bara, nyawang supe, lembehan, atrap sumping, ukel asta, dolanan sonder, atur-atur, menjangan ranggah, sekar suwun. Semuanya dilakukan dengan irama lamba dan ngracik, dengan sendi kengser ke kanan atau kengser ke kiri. Berdasarkan catatan yang ada, ternyata dapat diketahui bahwa ragam muryani busana yang dipergunakan, hanya dari kelompok ngadi busana, tidak satu pun menggunakan ragam gerak muryani busana dari kelompok ngadi sarira. Setelah muryani busana, gerak Golek selanjutnya berupa sekaran-sekaran. Dilihat dari geraknya secara keseluruhan, tak satu pun gerakan yang menggambarkan kontak langsung dengan peran yang lain. Hal ini memberi kesan masing-masing peran berdiri sendiri. Hal ini menjadikan makna golek yang berarti "mencari" tidak terletak pada geraknya, namun ada pada sebutan kata goleknya. Inti beksan berakhir ketika gending berganti ke Sekar Gendhing Pocung, dengan laras Slendro pathet Manyura dan penari melakukan gerakan sembahan dalam posisi duduk di tengah-tengah arena pentas.
Bagian terakhir adalah Mundur Beksan. Bagian ini merupakan kebalikan dari maju beksan. Mundur beksan juga tidak mempunyai makna yang berkaitan dengan tema, jadi semata hanya kebutuhan koreografi. Bagian ini merupakan saat mundurnya penari dari arena pentas. Seperti halnya maju beksan, hampir semua koreografi konvensional mempunyai bagian ini. Gerak sembahan yang dipakai untuk mengakhiri bagian inti beksan, sekaligus juga sebagai tanda dimulainya bagian mundur beksan. Setelah berdiri, gerakan yang dilakukan adalah kapang-kapang encot, menuju ke sebelah kanan arena pentas. Bagian ini berakhir ketika penari sudah sampai di pinggir kanan, duduk dan melakukan gerakan sembahan. Busana yang dipergunakan sama seperti Tari Golek yang lain.

Secara umum pengertian gambyong adalah sebuah tarian tunggal putri yang ada di khasanah tari Surakarta. Namun dalam tari gaya Yogyakarta, gambyong adalah nama salah satu peran yang ada dalam Tari Golek Gambyong. Gambyong adalah suami Golek, yang dalam tari ini menggambarkan seorang suami yang tidak tahu akan tanggungjawab dalam menghidupi istri, serta suka bermalas-malasan. Hal ini tercermin dalam dialog tembangnya yang berbunyi:

Kakang Gambyong prayogane, aja katungku ling kapti, luwih becik angupaya, pangerti praboting urip, apa kang sira pilih, gra menyang ngabdi priyagung.

Kakang Gambyong sebaiknya, jangan hanya berdiam diri, lebih baik berusaha, mencari kebutuhan hidup, apa yang kamu pilih, segeralah mengabdi pada priyagung (raja).

Roning bandhul baita, kayu gung rineka jalmi, karben hapa nganggo golek kang kangelan.

Roning bandhul baita (ini merupakan ungkapan), kayu dapat diolah manusia, mengapa harus mencari yang sulit.

Dalam hal gerak tarinya, peran Gambyong mempergunakan gerak gecul. (gerak gecul adalah gerak yang bernuansa komikal. Gerak ini biasanya dipergunakan oleh abdi atau pelayan dari seorang satria). Motif gerakan seperti yang dilakukan oleh 
Golek namun dalam kapasitas gecul. Gambyong merupakan gambaran orang yang ingin hidup enak tetapi tidak mau bekerja. Kesukaannya hanya bersenang-senang, seperti tersirat dalam teks tembang yang diucapkan Gambyong, yang sebagai berikut :

"Walang hijo larira, rak harani den himbu lami, hembuh-hembuh kudu sun sukak gambyongan".

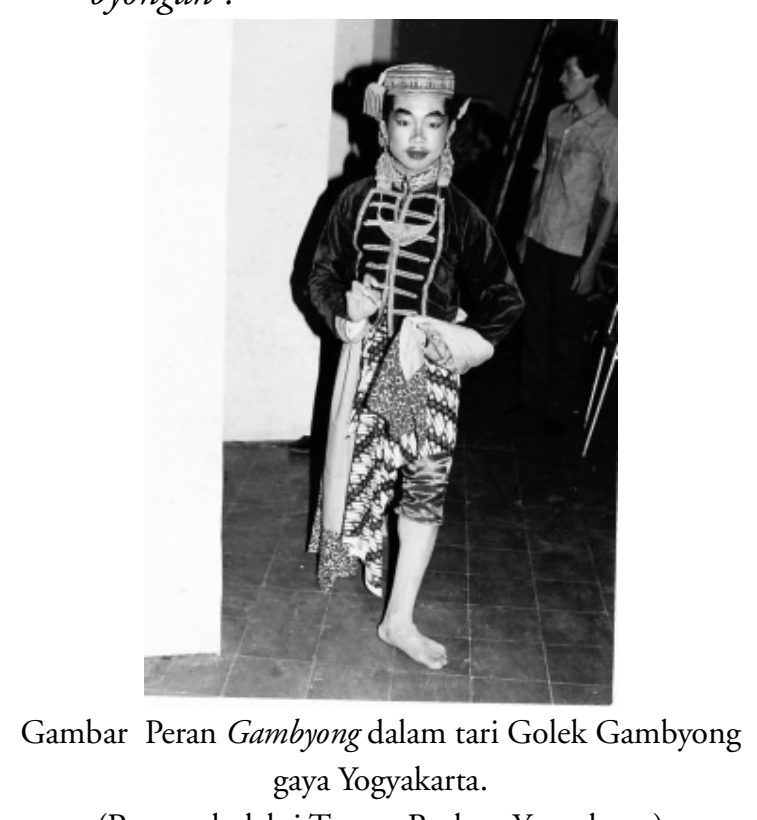

(Repro : koleksi Taman Budaya Yogyakarta)

Busana yang dipergunakan adalah : celana cindhen dengan model panji-panji, kain batik motif parang dengan model sapit urang, sabuk bara dengan kamus dan timang, berbaju beludru tanpa lengan, sampur_gendalagiri, ikat kepala dengan destar yang bermodel nyinthing asu nguyuh, berkalung tanggalan, kelat bahu model ngangrangan, kerisnya model gayaman, dan memakai kerincing (giring-giring) di kakinya.

Canthang Balung merupakan tokoh antagonis dalam Tari Golek Gambyong. Canthang Balung sebenarnya merupakan tokoh "asing" dalam budaya Yogyakarta, karena sebenarnya yang mempunyai Canthang Balung adalah keraton Kasunanan Surakarta. Di Surakarta, Canthang Balung adalah nama salah satu abdi dalem yang ikut dalam prosesi Garebeg Mulud tahun Dal.

Pada masa pemerintahan Sunan Paku Buwana X di keraton Kasunanan Surakarta, setiap upacara Garebeg Mulud yang jatuh pada tahun Dal, Sunan dan Permaisuri akan melakukan upacara menanak nasi. Upacara menanak nasi ini diadakan di dapur Gandarasan pada malam Garebeg. Kekhususan yang lain pada upacara Garebeg Mulud Dal, adalah dikeluarkannya dua pasang Canthang Balung. Canthang Balung adalah abdi dalem dari golongan Kridhastama. Abdi dalem Kridhastama adalah abdi dalem yang bertugas membuat orang lain gembira. Disebut Canthang Balung karena mereka membawa kepyak yang terbuat dari tulang yang diselipkan pada jari- jari, dan jika digerakkan akan berbunyi "crek, crek, crek". Dua pasang Canthang Balung yang berpangkat lurah dan jajar ini mudah dikenali karena memakai pakaian yang mencolok. Tugas Canthang Balung pada upacara Garebeg Mulud Dal adalah menyertai gunungan yang akan dibawa ke masjid. Dalam perjalanannya itu Canthang Balung melakukan gerak tari. Di keraton Surakarta kedudukan Canthang Balung selain sebagai pengiring gunungan saat upacara Garebeg, mereka juga berkedudukan sebagai abdi dalem niyaga, dan dahulu setiap Sabtu sore mereka bertugas mengiringi permainan watangan dengan gamelan. Namun permainan ini telah dihapus pada awal abad XIX. (Soeratman, 1989: 147) Walaupun upacara Garebeg di Surakarta dan Yogyakarta bertujuan sama, namun dalam pelaksanaannya banyak perbedaan di antara keduanya. Dalam prosesi Garebeg keraton Yogyakarta, tokoh Canthang Balung tidak ada. Demikian pula di upacara lain, tokoh ini tidak ada. Jadi keberadaan Canthang Balung pada Tari Golek Gambyong menjadi hal yang unik dan menarik. 


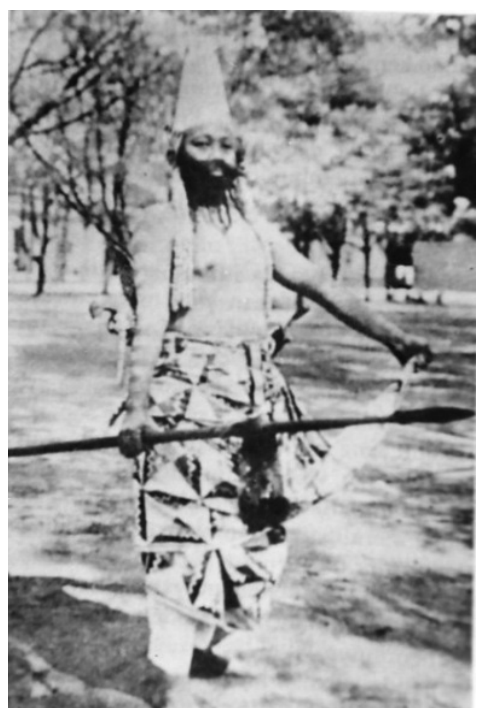

Gambar Canthang Balung yang ada di Keraton Surakarta. (Repro: Darsiti Soeratman, 1989, Kehidupan Dunia Kraton Surakarta, 1830-1939)

Keberadaan Canthang Balung juga ditulis dalam Serat Centini. Walaupun tidak diterangkan secara jelas, namun cukup diakui keberadaannya, seperti dituliskan bahwa :

...Sami dateng masjid, Mas Cebolang jiarah pasarean kasenopaten, saking masjid kaampiraken wismaning Ki Amongtrusta, Canthang Balung dipunladosi taledhek, klenengan.

(Semua pergi ke masjid, Mas Cebolang ziarah ke kuburan Kasenopaten, dari masjid disuruh mampir ke rumah Ki Amongtrusta, Canthang Balung dilayani tledek, bermain gamelan.

Canthang Balungdidalam Tari Golek Gambyong merupakan tokoh antagonis. Ia digambarkan sebagai tokoh yang unik. Keunikannya terlihat pada property yang dibawanya, yaitu tombak, tameng, pedang, keris, senapan, dan gada. Keadaan ini menunjukkan bahwa tokoh ini sebagai tokoh yang suka pamer dan tidak tahu diri. Dalam tari ini, Canthang Balung berusaha akan mendekati serta mengambil Golek. Usaha ini tidak pernah berhasil karena Golek selalu mengelak dan tidak menanggapi. Selain itu Gambyong sebagai suami Golek selalu menghalang-halangi. Canthang Balung boleh dikata tokoh yang nekad, tidak tahu diri, tetapi kocak. Ketika ia akan mewujudkan kemauannya, walaupun ia sudah tahu sebenarnya Golek sudah bersuami, namun ia tetap saja ber- usaha untuk mendekati. Ia tidak merasa bahwa sebenarnya kekuatannya jauh di bawah Gambyong. Ketika Canthang Balung tidak berhasil mendekati Golek, ia masih meminta kepada Gambyong dengan disertai ancaman, seperti tersirat dalam ucapannya yang berwujud tembang, yang dilantunkan oleh penarinya, berikut dialognya :

$\begin{array}{ll}\text { Canthang Balung }: & \text { Heh ta Gambyong } \\ & \text { Ngengehana, } \\ \text { Gambyong } & : \text { mbuh embuh nora preduli, } \\ \text { Canthang Balung }: \text { Hiya sira kang prayitna, } & \text { nadyan adoh hingsun bedhil } \\ & \text { rada cedhak hingsun } \\ & \text { tombak, } \\ & \text { yen luputa hingsun bithi, } \\ & \text { hingsun pedhang, hingsun } \\ & \text { mamah. }\end{array}$

Canthang Balung : Hai Gambyong berilah saya,

Gambyong : terserah tidak peduli

Canthang Balung : yah, hati-hatilah kamu, walaupun jauh saya tembak, agak dekat saya tombak, jika tidak kena saya pukul, saya pedang, saya kunyah.

Ragam gerak yang dipakai Canthang Balung adalah gerak gecul. Mengenai pola pola lantainya tidak ada ketentuan pasti, karena ia hanya menyesuaikan gerak dan pola lantai dari Golek dan Gambyong. Kadang-kadang ia akan mendekati Golek, tetapi tiba-tiba lari karena dihalangi oleh Gambyong. Kadang-kadang pula ia hanya dudukduduk sambil melihat dengan rasa kagum pada Golek. Kecenderungan improvisasi geraknya sangat tinggi, namun tetap dalam konteks gerak tari gaya Yogyakarta.

Kostum yang dipergunakan adalah: celana dengan model panji-panji, kain batik dengan model sapit urang, sabuk, bara dan kamus timang, baju lengan panjang, hiasan kepala berbentuk topi dengan model pacul gowang, memakai kalung tanggalan, buntal, oren, keris dengan model gayaman, berkaos kaki dan memakai krincing. 


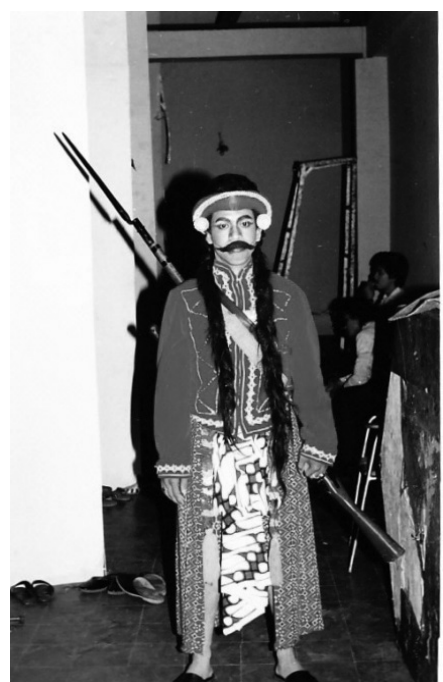

Gambar Canthang Balung dalam Tari Golek Gambyong gaya Yogyakarta.

(Repro: Koleksi Taman Budaya Yogyakarta)

\section{Makna Tari Golek Gambyong}

Seni merupakan manifestasi jiwa manusia yang sangat fleksibel, dalam arti di dalam seni dapat terkandung muatan yang sebetulnya di luar kepentingan atau fungsi seni itu sendiri. Berbagai tujuan dan latar belakang dapat untuk melandasi penciptaan seni. Pada hakekatnya karya seni adalah ekspresi jiwa manusia, karena itu dalam seni dapat termuat berbagai kemauan, demikian juga halnya untuk seni tari. Satu sisi karya tari dapat merupakan suatu eksperimen, yang merupakan manifestasi kegelisahan jiwa seorang seniman untuk berkarya yang sesuai dengan nuraninya. Namun di sisi yang lain berbagai alasan dapat melandasi penciptaannya, misalnya karena mendapat pesanan. Melalui penciptaan suatu karya tari, berbagai kepentingan dapat masuk di dalamnya. Karya tari dapat memuat bermacam-macam misi, misalnya misi pemujaan, ucapan syukur, hiburan, atau sebagai kritik sosial. Karya tari dapat merupakan penggambaran keadaan yang terjadi di sekitarnya, seperti halnya dalam Tari Golek Gambyong ini. Melihat beberapa keunikan yang ada di dalamnya, menjadikan menarik untuk dapat diketahui latar belakang atau misi yang dikandungnya.

Makna dari peran Golek yang ada di dalam Tari Golek Gambyong adalah mencari inti dari tari itu sendiri. Oleh karenanya tulisan ini mengarah pada upaya untuk mencari intinya dan menguak misteri yang melatarbelakangi penciptaannya. Secara sepintas Tari Golek
Gambyong merupakan panggambaran adanya suatu perselisihan, namun tidak jelas perselisihan yang terjadi menggambarkan antara siapa dengan siapa, dan ini tidak biasa terjadi dalam koreografi klasik Yogyakarta (di dalam koreografi Jawa, permasalahan biasanya digambarkan secara jelas dalam lakon dan penokohannya. Misalnya Bedhaya Parta Krama, yang menggambarkan perkawinan antara Arjuna dengan Dewi Sembadra, beksan Rengganis Widaninggar yang menggambarkan perangnya tokoh Rengganis dengan tokoh Widaninggar, dan sebagainya). Ketidakjelasan itu menyebabkan berbagai kemungkinan dan dugaan dapat terjadi, terlebih tidak adanya data tertulis yang menyebutkan latar belakang diciptakannya Tari Golek Gambyong. Namun yang jelas pada awal penciptaan dan perkembangannya, di dalam keraton sedang terjadi intrik politik yang terkenal dengan nama pergolakan Suryengalaga (18551883) (Sudiro, 1986).

Pada dasarnya dalam pergolakan ini, yang berseteru adalah pihak Hamengku Buwana VII dan P. Suryengalaga. Namun sejarah juga mengatakan, bahwa pihak Belanda yang ketika itu sebagai penjajah selalu ambil peranan. Dengan demikian ada tiga pihak yang muncul dalam konflik itu. Peristiwa inilah yang menarik penulis untuk mengarahkan teba tafsir bahwa makna Tari Golek Gambyong adalah sebagai penggambaran kritik bagi pihak yang bergolak. Analisis ini didasari bahwa pencipta tari ini adalah K.G.P.A. Mangkubumi putera dari Sultan Hamengku Buwana VI, yang suatu saat akan menggantikan ayahandanya. Sangat dimungkinkan sekali dalam masa penantiannya itu timbul juga kekhawatiran, karena selain K.G.P.A. Mangkubumi ada juga "calon lain yang berhak" untuk menggantikannya yaitu P. Suryengalaga putera Hamengku Buwana $\mathrm{V}$.

Dalam Serat Raja Putra Ngayogyakarta Hadiningrat, terdapat dua nama Suryengalaga. Pertama, Bendara Pangeran Harya Suryengalaga (B.P.H. Suryengalaga) yang sebelumnya bernama Bendara Pangeran Harya Hadinegoro. B.P.H. Suryengalaga adalah putra kedua dari Hamengku Buwana III dengan garwa ampean (selir) Raden Ayu Puspitalangen. Suryengalaga, yang kedua adalah Gusti Pangeran Harya Suryengalaga putra Hamengku Buwana V dengan garwa padmi (permaisuri) Gusti Kangjeng Ratu Sekar Kedhaton. 
G.K.R. Sekar Kedhaton adalah putra dari B.P.H. Suryengalaga. Jadi G.P.H. Suryengalaga adalah cucu dari B.P.H. Suryengalaga. (Mandoyokusumo, K.R.T., 1980: 27-42) Sedangkan yang dibahas dalam tulisan ini adalah G.P.H. Suryengalaga. Dalam tradisi Jawa, penggunaan nama yang sama antara ayah dengan putera atau kakek dengan cucu adalah hal yang wajar, dinamakan nunggak semi.

Dasar terjadinya pergolakan karena adanya perebutan tahta kekuasaan kerajaan Yogyakarta. Kekuasaan sendiri menurut Weber adalah kemungkinan seorang pelaku mewujudkan keinginannya di dalam suatu hubungan sosial yang ada termasuk dengan kekuatan atau tanpa menghiraukan landasan yang menjadikan kebijakan itu. Sedangkan menurut Parsons kekuasaan sebagai suatu sumber sistem, kekuasaan merupakan suatu kemampuan untuk menjamin pelaksanaan kewajiban yang mengikat (terhadap tujuantujuan kolektif yang telah disepakati). Di dalam suatu sistem organisasi kolektif, jika satuan-satuan di dalamnya ada perlawanan maka lembaga yang berkuasa perlu menegakkannya dengan sanksisanksi situasional yang bersifat negatif (Roderick Martin, 1990: 70 - 75). Kekuasaan di dalam konteks ini adalah kekuasaan yang dimiliki oleh seorang raja. Raja adalah seseorang yang menyatukan pelaksanaan kekuasaan tertinggi dan berbagai-bagai lambang yang bersifat magis dan mistis, yang menyatukan kualitas perlengkapanperlengkapan itu.(Sartono Kartodirdjo, 1975: 255)

Konflik mulai terjadi setelah Sri Sultan Hamengku Buwana V mangkat pada tgl. 5 Juni 1855, yang ketika mangkat belum mempunyai putra mahkota. Berdasarkan data yang tertulis di Serat Raja Putra Ngajogjakarta Sri Sultan Hamengku Buwana V mempunyai dua permaisuri yaitu Gusti Kanjeng Ratu Kencana dan Gusti Kanjeng Ratu Kedhaton, serta tiga selir yaitu Bendara Raden Ayu Dewaningsih, Bendara Raden Ayu Panukmowati, dan Raden Ayu Retno Wulan. Dari kelima istrinya, lahir 9 putra putri Sultan. Tetapi yang hidup hingga dewasa hanya empat orang, yaitu : B.R.Ay. Gusti Hangabehi, B.R.Ay. Hadiwinoto, B.R.Ay. Mangkubumi, yang ketiganya lahir dari garwa ampeyan (selir), dan G.P.H. Suryengalaga yang lahir dari permaisuri G.K.R. Sekar Kedhaton. P. Suryengalaga lahir pada tanggal 17 Juni 1855, ketika kecil bernama R.M. Mohamad atau R.M. Akhidat. Setelah diwisuda menjadi Pangeran lebih terkenal dengan sebutan P. Suryengalaga. Jadi sebagai "putra mahkota" P. Suryengalaga lahir 12 hari setelah ayahandanya meninggal. Hal ini menjadi masalah, karena ada beberapa pendapat bahwa sebagai putra mahkota harus sudah lahir sebelum ayahnya meninggal. Dikenal stratifikasi bagi para istri raja di kraton, istri pertama, garwa padmi atau permaisuri; kedua, garwa ampeyan atau selir; dan yang ketiga adalah pelara-lara atau klangenan. Yang berhak menjadi calon raja atau putra mahkota adalah putra laki-laki yang tertua dari permaisuri, namun jika permaisuri tidak mempunyai putra laki-laki, putra dari seorang selir dapat menggantikannya.

Jeda waktu antara meninggalnya Sultan Hamengku Buwana V dan kelahiran Pangeran Suryengalaga, adalah awal dari silang pendapat, yang pada gilirannya menumbuhkan suatu pergolakan, walaupun pada awalnya tidak secara langsung dan belum mencuat ke permukaan. Permasalahan pada waktu itu adalah siapa yang berhak sebagai pengganti raja. Ketika itu ada dua spekulasi pendapat, yang pertama adalah P. Suryengalaga, dengan alasan ia adalah anak laki-laki yang dilahirkan dari permaisuri, walaupun kelahirannya setelah ayahndanya meninggal. Pendapat kedua adalah bukan P. Suryengalaga, dengan alasan karena ia masih bayi dan kelahirannya setelah ayahnya meninggal, maka menurut adat tidak ada lagi hak sebagai putra mahkota. Dengan demikian harus dicarikan alternatif lain. Dengan berbagai macam pertimbangan, sebagai calon terkuat adalah G.R.M. Mustaja. Perbedaan pendapat ini menjadi besar karena dari kedua belah pihak mendapat dukungan dari orang-orang yang mempunyai peranan dalam kerajaan. Pada akhirnya dengan berbagai alasan pihak Belanda cenderung menyetujui atau berpihak pada alternatif yang kedua. (Sudiro, 1986: 4)

Adanya spekulasi calon raja ternyata hanya berlangsung satu bulan, karena pada tgl 5 Juli 1855 Gusti Raden Mas Mustaja dinobatkan menjadi raja dengan gelar Ngarsadalem Sampeyandalem Hingkang Sinuwun Kangjeng Sultan Hamengku Buwana Senapati Hing Ngalaga Ngabdurrahman Sayidin Panatagama Kalifatullah Hingkang Jumeneng_Kaping Enem. G.R.M. Mustaja adalah adik kandung laki-laki dari Hamengku Buwana V, 
putra Hamengku Buwana IV dengan permaisuri Gusti Kangjeng Ratu Kencana atau Gusti Kangjeng Ratu Hageng. G.R.M. Musteja lahir pada tanggal 10 Agustus 1821. Jadi ketika dinobatkan menjadi raja berusia 34 tahun. Pejabat yang mengangkat adalah Tuan Gubernur Jendral Albertus dan Djanoedimer. (Serat Radja Poetra Ngajogjakarta: 26) Penobatan G.R.M. Mustaja sebagai Hamengku Buwana VI dapat diterima pihak P. Suryengalaga, dengan alasan P. Suryengalaga masih kecil, jadi masih memerlukan wali. Namun demikian penerimaan itu dengan harapan suatu ketika tahta akan dikembalikan/ diberikan lagi padanya.

Sri Sultan Hamengku Buwana VI meninggal pada tgl 20 Juli 1877, dan dimakamkan di Pajimatan Imogiri, Kedhaton Besiyaran. Selama 22 tahun pada masa pemerintahan Hamengku Buwana VI, keadaan boleh dikata tenang dan tenteram. Walaupun dalam ketenangan itu pihak P. Suryengalaga tetap mengupayakan haknya sebagai putra mahkota, yang antara lain dengan memohon gelar pangeran pada raja, dan meminta tanah lungguh di Pengasih, Gunung Kidul, Nanggulan, Kalibawang dan Sentolo. Tempattempat ini dipilih, karena merupakan "haknya sebagai calon raja”. Tidak semua permohonan itu dikabulkan, hanya permohonan sebagai pangeran saja yang dikabulkan. Permohonan itu mendapat persetujuan dari Resident Belanda. Demikian juga pihak Hamengku Buwana VI, secara khusus telah mempersiapkan diri untuk mengantisipasi keadaan mendatang, khususnya dalam pergantian takhta, yang diramalkan akan menghadapi kendala dari pihak P. Surjengalaga sebagai pihak yang merasa "memiliki hak" untuk mengantikannya. (Sudiro, 1986: 39)

Ketika meninggal, Hamengku Buwana VI meninggalkan dua permaisuri dan lima selir dengan 23 putra-putri, tetapi yang tiga orang meninggal ketika masih kecil. Putra sulung HB VI adalah seorang lelaki yang diberi nama Gusti Raden Mas Murteja, yang lahir dari permaisuri Gusti Kanjeng Ratu Sultan atau Gusti Kanjeng Ratu Hageng. (Mandayakusuma 1975: 45-47) Dalam keraton, raja mempunyai istri dan anak banyak adalah hal biasa, dan ini merupakan salah satu politik raja untuk mendapatkan dukungan yang lebih banyak.
Setelah meninggalnya Hamengku Buwana VI maka timbul lagi permasalahan lama, yaitu siapa yang akan menggantikannya sebagai raja. Apakah takhta itu akan "dikembalikan" pada P. Suryengalaga atau diberikan pada salah satu putranya, yang kebetulan putra sulung dari permaisurinya yang melahirkan putra laki-laki. Misteri tentang siapa calon pengganti raja ternyata juga tidak lama, karena kurang dari satu bulan, tepatnya tanggal 13 Agustus 1877 pihak penguasa kerajaan dan Belanda telah menggunakan otoritasnya untuk mengangkat Gusti Raden Mas Murteja, putra Hamengku Buwana VI untuk menggantikannya. Alasannya sangat jelas, karena Hamengku Buwana VI mempunyai putra sulung laki- laki yang tentunya berhak menjadi putra mahkota. Walaupun sebenarnya tahta yang diembannya semula hanya merupakan "pinjaman", namun sebagai raja Hamengku Buwana VI tentu saja tetap mempunyai otoritas, yang pada saatsaat tertentu dapat saja dipergunakan. Otoritas menurut Parsons sebagai keunggulan yang mencakup hak dan/ atau kewajiban yang sah untuk mengendalikan tindakan-tindakan pihak lain di dalam sistem hubungan social.(Martin, 1990: 82). Dalam konsep Jawa Sultan dipandang sebagai seseorang yang dianugerahi kerajaan dan kekuasaan politik, militer dan keagamaan yang absolut. Sultan merupakan sumber satu-satunya dari kekuasaan (Soemardjan, 1981: 23-34). Pengangkatan Gusti Murteja sebagai raja secara jelas digambarkan dalam Babad Suryengalagan, seperti tertulis:

Djeng toewan Minister Noeli, djoemenengnya maos palekat, kathah-kathah pitemboenge, kang soerasa djoemenengnya, Sinoewoen Kangdjeng Soeltan, Amengkoe Boewana Agoeng, Senapati ing Ngalaga.

Ngabdoelrahman ja sajidi, Panatagama Kalipah, Ping Pitoe Ngajoegja mangke, Djeng Goepoermen soepeketnja, pawang mintra sih tresna, mestoe- deya ngangkat toehoe, kaloehoeraning narendra.

Sak soeroede poetra mami, djeng Soeltan ping nem Ngajoegja, karsanira djeng Goepermen, sagoeng pangwasa nagara, pan woes pratjaja marang, wajahsoen sang radja soenoe, ing mangkeja wajah ingwang. 
Karsa djoemeneng nrapati, soemilih kratoning ejang, ejang leloehoer praradjeng, soekaboedhi- dajanja, Goepermen bjantoe ngangkat, wit dibja oetana kasoeb, manganah pradja dikarta. (Babad Suryengalagan)

(Segera tuwan Minister, berdiri membaca plakat, banyak sekali ucapannya, tentang pengangkatan, Sinuwun Kangjeng Sultan, Hamengku Buwana Agung, Senapati Ing Ngalaga.

Ngabdulrahman Sayidin, Panatagama Kalifatulah yang ketujuh, telah disepakati Gupermen, semua sanak saudara ikut mendukung, keberadaan raja.

Sepeninggalannya Sultan ke VI, menurut kehendak Goepermen dan para pejabat negara, telah mempercayakan kepada anaknya yang juga cucu raja.

Akan dinobatkan menjadi raja, menggantikan keberadaan kakeknya, para leluhurnya, karena upayanya, yang dibantu Goepermen.)

Menurut nota penjelasan pada lampiran Handelingen van de Staten Generaal (Risalah Dewan Perwakilan Kerajaan Belanda), G.R.M. Murteja atau Sri Sultan Hamengku Buwana VII adalah anak tidak syah dari Hamengku Buwana VI. Ia ditunjuk sebagai sultan dengan surat keputusan Gubernur Jenderal Hindia Belanda yang bertanggal 17 April 1872, karena tidak adanya putera sultan yang syah. Namun istilah putera yang tidak syah ini tidak benar. Ketika itu permaisuri Hamengku Buwana VI, Gusti Kanjeng Ratu Sasi yang berasal dari keraton Solo, hanya melahirkan seorang putri, maka ibu Hamengku Buwana VI yang ketika itu sebagai selir kemudian diangkat sebagai permaisuri. Setelah itu G.R.M. Murteja yang telah bergelar Gusti Pangeran Hangabehi diangkat menjadi putera mahkota dengan nama Kanjeng Gusti Pangeran Hadipati Hanom Hamengku Negoro (Poerwakoesoemo, 1985). Dikenal istilah kuluk di keraton yaitu seorang raja yang menceraikan istriya untuk menikah dengan "istrinya yang lain". Ini terjadi bila kebetulan raja memiliki istri lebih dari empat orang pada waktu yang bersamaan, padahal menurut hukum hanya boleh beristrikan empat orang. Maka raja akan menceraikan salah satu istrinya yang tidak hamil, kemudian menikahi istrinya yang hamil yang sebelumnya belum dinikah. Jika kebetulan (walaupun jarang terjadi) keempat istrinya yang syah semuanya hamil dan ada istri lagi yang harus dinikah, biasanya salah satu darinya akan diberikan atau dihadiahkan (dipuntrimakaken) pada abdi dalem atau pada orang yang dianggap pantas untuk menerima. Pihak P. Suryengalaga ternyata tidak bisa menerima kenyataan dengan adanya pengangkatan itu. Dengan diangkatnya G.R.M. Murteja menjadi raja, berarti pupus sudah harapan P. Suryengalaga untuk menjadi raja. Keadaan inilah yang menyulut pecahnya pergolakan.

Sebelum pecahnya pergolakan, pihak $P$. Suryengalaga sebetulnya sudah berupaya untuk mendapatkan haknya dengan cara halus, yaitu berusaha untuk menjadi menantu sultan. P. Suryengalaga sedianya akan mengambil salah satu putri sultan yang lahir dari permaisuri Gusti Kanjeng Ratu Kencono (sebelum dikebonkan). Namun maksud tersebut tidak terlaksana, karena Hamengku Buwana VII tidak menyetujui. Alasannya karena P. Suryengalaga telah dianggap sebagai lawan, maka perkawinan itu tidak pantas dilakukan. (Sudiro 1986: 47)

Dengan gagalnya beberapa usaha yang dilakukan, dan jalan musyawarah nampaknya sudah tidak terbuka lagi, berarti pupus sudah harapan P. Suryengalaga untuk mendapatkan haknya dengan jalan damai. Oleh karena itu jalan satu-satunya untuk mewujudkan harapannya adalah merebut dengan cara kekerasan. Upaya melaksanakan rencananya, P. Suryengalaga yang dibantu ibundanya G.K.R. Kedhaton kemudian bergabung dengan G.K.R. Kencono mantan permaisuri Hamengku Buwana VII. alasan G.K.R Kencono bergabung dengan P. Suryengalaga adalah untuk melawan Hamengku Buwana VII, karena merasa sependeritaan dan sakit hati setelah dikebonkan oleh Hamengku Buwana VII. Disamping itu P. Suryengalaga juga mendapat dukungan dari H. Istad salah satu kerabat G.K.R. Kedhaton yang berpengaruh dan mempunyai banyak pengikut, serta mendapat dukungan pula dari beberapa abdi dalem dan rakyat yang setia pada P. Suryengalaga. Namun di samping mendapat dukungan, banyak juga para sentana dalem yang berusaha mengingatkan P. Suryengalaga, di 
antaranya adalah R.M. Sumodiprojo dan K.R.T. Sumodiningrat kakak dari G.K.R. Kedhaton. Mereka mengingatkan tentang untung ruginya bila rencana yang dibuat P. Suryengalaga itu dilaksanakan. Demikian besar tekad P. Suryengalaga untuk bisa mendapatkan haknya, hingga tak satu pun nasehat yang diberikan kepada P. Suryengalaga yang dituruti. Dengan tekad yang bulat, walaupun harus dengan kekerasan seperti yang terlihat dalam sumpahnya yang diucapkan sebelum memulai bergerilya, bahwa "lebih baik meninggal bila tidak dapat menjadi raja”, maka sumpah itu juga diucapkan oleh G.K.R. Kedhaton dan para pengikutnya di Keraton Kulon. Para pengikutnya itu antara lain : R.M. Banteng, R.M. Sumadipraja, R.M. Sudigbya, Prawiradijaya, dan Purwaatmaja. (Sudiro, 1986: 52)

Dalam kemantapannya itu sebetulnya P. Suryengalaga juga tidak terlalu yakin akan keberhasilan usahanya. Hal itu mengingat kekuatan yang dimiliki tidak seimbang dengan kekuatan pihak Hamengku Buwana VII, apalagi pihak Hamengku Buwana VII masih mendapat bantuan dari pihak Belanda. Namun demikian rencana itu tetap dilaksanakan, karena menurut $P$. Suryengalaga maju atau mundur akan berakibat sama. Berdasarkan pengalaman sebelumnya, biasanya akan ditangkap kemudian dibuang atau dipenjara karena dianggap bersalah. Akhirnya diputuskan P. Suryengalaga, G.K.R. Kedhaton dan para pengikutnya keluar meninggalkan keraton. Rombongan dibagi menjadi tiga kelompok, yang masing-masing dipimpin P. Suryengalaga, G.K.R Kedhaton dan Haji Istad. (Sudiro, 1986: 50)

Dalam mengatasi pergolakan itu, pemerintah mengeluarkan peraturan bahwa,semua penduduk dilarang menerima, memberi bantuan atau perlndungan pada P. Suryengalaga dan bala tentaranya. Adanya peraturan itu, ternyata cukup membuat sulit pihak P. Suryengalaga. Apalagi ada beberapa abdi dalem yang kemudian berbalik kembali ke keraton, dan beberapa abdi dalem yang masih mengikuti P. Suryengalaga bersikap mendua. Keadaan ini menjadikan P. Suryengalaga semakin terdesak, akhirnya hanya orang-orang tertentu saja yang kebetulan mempunyai hubungan khusus yang mau menerima.

Menyusul dikeluarkannya peraturan itu, Hamengku Buwana VII dibantu Belanda mengirim utusan yang dipimpin Tumenggung Anggawangsa untuk membujuk P. Suryengalaga, G.K.R. Kedhaton dan pasukannya agar mau kembali ke keraton serta mau membatalkan niatnya, serta mau bekerja sama dengan pemerintah yang syah. Seperti tersurat dalam Babad Suryengalagan, bahwa:

"Anggawangsa awotsari, kawoela dateng send$i k a$, nging menggah wonten angele, kadreng mring karsa miroeda, poenapa amba roda, lawan yen tjawengakipoen, ing karsa bilih satemah".

"Mring amba ambebayani, poenapa kinging linawan, sang mantrimoeka dawoehe, yen angel sira peksowa, matoera lamoen ingwang, ingkang ngatoeri kondoer, yen karsa bandjoer djoedjoegna".

(Anggawangsa berkata, saya bersedia, tetapi kalau ada kesulitan, karena kemauannya kuat, apakah saya boleh memaksa, dan apabila terpaksa, kehendaknya menimbulkan akibat.

Sehingga berbahaya bagi diri saya, apakah boleh dilawan, Sang Mantrimuka memerintah, kalau sulit harus kamu paksa, katakan kalau saya yang memerintahkan pulang, jika mau bawalah menghadap).

Utusan itu dibekali senjata lengkap, mengingat sebelumnya pernah terjadi pertempuran kecil antara pasukan Hamengku Buwana VII yang dibantu Belanda dengan pasukan P. Suryengalaga. Dalam pertempuran itu dari masing- masing pihak jatuh korban. Akibat dari pertempuran itu, pemerintah Hamengku Buwana VII menganggap P. Suryengalaga memiliki kekuatan yang cukup berbahaya. Ternyata usaha untuk membujuk berhasil tanpa disertai kekerasan. Walaupun pada awalnya ada ketegangan, tetapi mengingat kekuatan yang dimiliki, akhirnya $P$. Suryengalaga menyerah dengan syarat untuk kembali ke keraton minta dijemput dengan kereta berkuda untuk dinaiki P. Suryengalaga dengan pasukannya. Demikian juga rombongan G.K.R. Kedhaton, pada akhirnya juga mau menyerah pada utusan Hamengku Buwana VII karena akan dijamin keselamatannya. Sedangkan yang terjadi pada rombongan yang dipimpin Haji Istad agak lain, karena adanya kesalahpahaman, terjadilah bentrokan fisik yang mengakibatkan terbunuhnya 
H. Istad.(Sudiro, 1986: 51-50)

Setelah terjadi penangkapan, pemerintah mengadakan persidangan untuk mengetahui besar kecilnya kesalahan. Pada persidangan itu, biasanya bila kesalahan tertuduh dianggap kecil, maka ia hanya dimintai keterangan lalu dibebaskan. Jika kesalahannya dianggap tidak terlalu besar kemudian ditangkap dan dipenjarakan. Bagi orang yang dianggap mempunyai kesalahan besar, hukumannya berupa pembuangan/ pengasingan ke luar Pulau Jawa. Mereka yang dibuang antara lain: P. Suryengalaga, seorang istrinya, seorang anaknya, serta G.K.R. Kedhaton dan dua puluh satu kerabat serta abdi dalem yang setia. Mereka dibuang ke Menado. Seperti yang tertulis dalam Babad Suryengalagan, bahwa:

"Priksa kang dadi atoernya, dening toewan roesmejer kontrolir, lan kinanten djeksa agoeng, rijo Nitidipoera, sanes karsaning atoer soerat sinebat, pinrih ngoeloer nalar, samja pepet moeng ngantepi".

"Semana Minister pyambak, kintoen kawat marang Menado nagri, arsa kirim Kangdjeng ratoe, lan Pangran Soerjengalaga, saabdi lan sentana doemoenoeng ngrikoe, wit karja obahing pradja, mring wlanda karja pepati”.

"Moetek ametek kagagas, samja moewoes soemarah marang pesti, prapta oebaja ning lakoe, bidale kangdjeng pangran, lan djeng ratoe ingaleraken winot sepoer, sapoetra miwah klangenan, doek pangkate sangking lodji”.

(Seperti yang dikatakan, oleh tuan Roesmejer kontrolir, disertai jaksa agung, Rio Nitidipoera, lain hal yang tersebut dalam surat, supaya dipikirkan, semua terpaksa menyetujui.

Ketika itu tuan Minister sendiri, mengirim kawat ke Menado, akan mengirim kanjeng Ratu, dan pangeran Suryengalaga, beserta pembantu dan saudaranya kesana, karena telah menggoncangkan pemerintahan, telah pernah membunuh Belanda.

Dipikirkan dengan masak, semua menerima pada putusan, untuk perjalanannya, keberangkatan Kanjeng Pangeran, dan Djeng Ratu naik kereta api, dengan anak dan apa yang disenangi, berangkatnya dari loji).

\section{Penutup}

Tari Golek Gambyong, merupakan tari yang mempunyai konsep yang berbeda dengan bentuk Tari Golek yang lain, karena perbedaannya itu, menjadikan tari ini menarik untuk dikaji. Diperkirakan tari ini dibuat sebagai penggambaran adanya intrik yang ada atau sebagai sindiran bagi pihak P. Suryengalaga. Hal ini sesuai dengan keterangan dari salah satu narasumber tari tersebut, walaupun narasumber tidak secara jelas menyebutkan bahwa tari tersebut merupakan sindiran bagi pihak P. Suryengalaga. Namun hanya dikatakan bahwa tari tersebut mempunyai hubungan dengan suasana yang ada di keraton pada saat itu.

Setelah dianalisis tiga peran yang ada di dalam Tari Golek Gambyong, masing-masing merupakan gambaran dari pihak pemerintahan yang syah, Belanda, dan pihak P. Suryengalaga. Peran Golek dan Gambyong merupakan satu pihak yang kelihatannya satu tetapi dua. Maksudnya merupakan penggambaran yang sebenarnya terjadi antara Sultan dan Belanda. Dalam "kebersamaannya", masing-masing mempunyai alasan dan kepentingan yang berbeda. Sementara pihak Belanda "membantu" karena ingin lebih menguasai dan mungkin ada maksud lain, sementara keadaan yang demikian sebenarnya bukan yang dikehendaki Sultan. Pada situasi dan kondisi yang demikian kemungkinan Sultan mau "bersatu" hanya karena tidak adanya pilihan lain, terutama dalam menghadapi P. Suryengalaga. Hal ini dapat dilihat dalam Tari Golek Gambyong, yaitu dengan tidak adanya kesatuan pendapat dan tujuan di dalam keseharian pada tokoh Golek dan Gambyong. Namun mereka bersatu ketika menghadapi Canthang Balung yang akan mengambil Golek. Dalam hal ini merupakan penggambaran dari P. Suryengalaga yang akan merebut tahta dari pemerintahan yang syah. Peran Gambyong sebagai penggambaran seorang suami yang dalam konteksnya sebagai penentu keputusan, dalam peristiwa ini setara dengan kedudukan Belanda yang seringkali mendominasi keputusan di dalam pemerintahan Sultan. 


\section{Kepustakaan}

Babad Suryengalagan, MS koleksi Museum Sana Budaya no: PB E 9

Kartodirdjo, Sartono. 1975. Sejarah Nasional Indonesia. Jakarta: Departemen Pendidikan Dan Kebudayaan.

Mandoyokusumo, K.R.T. 1980. Serat Raja Putra Ngayogyakarta Hadiningrat. Yogyakarta: Bebadan Museum Karaton Ngayogyakarta Hadiningrat.

Martin, Roderick. 1990. Sosiologi Kekuasaan. terj. Herry Joediono. Jakarta: CV.

Rajawali.

Soeratman, Darsiti. 1989. Kehidupan Dunia Kraton Surakarta 1830-1939. Yogyakarta: Penerbit Taman Siswa Yogyakarta.

Soemardjan, Selo. 1981. Perubahan Sosial di Yogyakarta, Yogyakarta: Gadjah Mada University Press.
Serat Raja Putra Ngajogjakarta,1833. M.S koleksi Museum Sana Budaya Yogyakarta, no: SB 64, p. 26.

Sudiro. 1986. "Pergolakan Suryengalaga Di Yogyakarta Periode 1855-1883", Tesis untuk Program Studi Sejarah Jurusan Ilmu-ilmu Humaniora Fakultas Pasca Sarjana Universitas Gadjah Mada.

Poerwakoesoemo, Soedarisman.1985. Kasultanan Yogyakarta, Yogyakarta: Gadjah Mada University Press.

Winarti, Tutik. 1997. "Tari Golek Gaya Yogyakarta Sebuah Akulturasi Budaya Rakyat dan Istana” Tesis untuk program Pengkajian Seni Pertunjukan Jurusan Ilmu-ilmu Humaniora, Fakultas Pasca Sarjana Universitas Gadjah Mada. 